\title{
Semen characteristics of the endangered cyprinid lake minnow, Eupallasella percnurus (Pall.), from different Polish populations
}

\author{
Justyna Sikorska, Sylwia Judycka, Rafał Kamiński, Jacek Wolnicki
}

Received - 14 July 2020/Accepted - 26 November 2020. Published online: 31 December 2020; $\odot$ Inland Fisheries Institute in Olsztyn, Poland Citation: Sikorska J., Judycka S., Kamiński R., Wolnicki J. 2020 - Semen characteristics of the endangered cyprinid lake minnow, Eupallasella percnurus (Pall.), from different Polish populations - Fish. Aquat. Life 28: 200-204

\begin{abstract}
The aim of the study was to compare the quality and quantity parameters of semen in male lake minnow, Eupallasella percnurus (Pallas, 1814), from six Polish populations. Substantial differences among the populations were found in milt volume (36-112 $\mu \mathrm{l})$ and sperm concentration $\left(4.7-8.0 \times 10^{9} \mathrm{ml}^{-1}\right)$. Mean values for sperm motility were similar; however, there were population-related differences in sperm velocity measured with VSL (96.3-127 $\mu \mathrm{m} \mathrm{s}^{-1}$ ). Despite this, the quality of semen in all cases was high and appropriate for both artificial reproduction and cryopreservation.
\end{abstract}

Keywords: milt volume, sperm motility, hormonal stimulation, endangered species, Eupallasella percnurus

\section{Introduction}

The lake minnow, Eupallasella percnurus (Pallas, 1814), is a small cyprinid fish that is threatened with extinction in Poland, and it is strictly protected by law including the formal requirement of active

J. Sikorska [ ఏ], R. Kamiński, J. Wolnicki

Pond Fishery Department, Inland Fisheries Institute,

Główna 48 St., Żabieniec, 05-500 Piaseczno, Poland

e-mail: j.sikorska@infish.com.pl

\section{S. Judycka}

Department of Gametes and Embryo Biology, Institute of Animal Reproduction and Food Research, Polish Academy of Sciences, Olsztyn, Poland protection (Kaczmarczyk and Wolnicki 2016, Sowińska-Świerkosz et. al. 2019). Consequently, different approaches to active protection have been implemented to date (Wolnicki et al. 2019), and the most common involve initiating new populations by translocating juvenile fish originating from aquaculture (Wolnicki et al. 2011, 2018). The basis of this approach is the controlled reproduction of mature fish, egg incubation, and rearing of early stages to the size of $0.5-1.0 \mathrm{~g}$, which is appropriate for translocation.

General knowledge on these topics is already quite advanced (Kamiński et al. 2011, Dietrich et al. 2014, 2015, Wolnicki et al. 2018, 2019); however, very little is known about the qualitative and quantitative characteristics of lake minnow semen. Knowledge is also limited concerning natural diversity in quality and quantity parameters of semen from different populations. Preliminary results suggested that there might be distinct differences in sperm quality among populations, but these studies have been conducted on scarce material concerning only one or two populations (Dietrich et al. 2011, 2014). Therefore, the aim of the present study was to compare basic quantitative and qualitative parameters of semen in lake minnows from six Polish populations to assess its suitability for the active protection of this species through artificial reproduction. 


\section{Materials and Methods}

Lake minnow males of unknown age were collected from six populations located in a large part of the range of occurrence of this species in Poland (Fig. 1). The main differences observed in these habitats included water surface and water depth (0.5-2.0 $\mathrm{m})$ and physicochemical features like water $\mathrm{pH}$ and electrolytic conductivity (Table 1). Fifty fish specimens were caught from each population in May 2016 at a water temperature close to $18^{\circ} \mathrm{C}$. Next, they were transported to a laboratory and acclimated for two weeks in six separate $200 \mathrm{l}$ flow-through tanks to the following conditions: water temperature $15^{\circ} \mathrm{C}$ (range \pm $\left.0.5^{\circ} \mathrm{C}\right), \mathrm{pH}=7.8-7.9$, oxygen saturation $80-90 \%$, and a water exchange rate of $11 \mathrm{~min}^{-1}$. The fish were not fed during the acclimation period.

Hormonal stimulation was applied according to the method described by Kamiński et al. (2004) and was approved by the Local Ethic Committee for Animal Experiments (No. $15 / 2015)$. All the fish were intraperitoneally injected with a single dose of Ovopel $^{\odot}(2$ pellets per $\mathrm{kg}$ ), which is a mammalian GnRH analog with a dopamine receptor antagonist (D-Ala ${ }^{6}$, Pro ${ }^{9}$-Net-mGnRH; Unic-trade, Hungary). Prior to injection, the agent was homogenized in a $0.9 \% \mathrm{NaCl}$ solution (Horváth et al. 1997). In the six hours following injection, the water temperature was gradually increased from $15^{\circ} \mathrm{C}$ to $18^{\circ} \mathrm{C}$. The fish sperm was collected $24 \mathrm{~h}$ after the injection by gentle abdominal massage. Samples were collected individually taking care to avoid contamination. All fish manipulations were done after mild anesthesia was applied by immersing the fish in a $80 \mathrm{mg} \mathrm{l}^{-1}$ MS-222 solution (Argent Laboratories, USA).

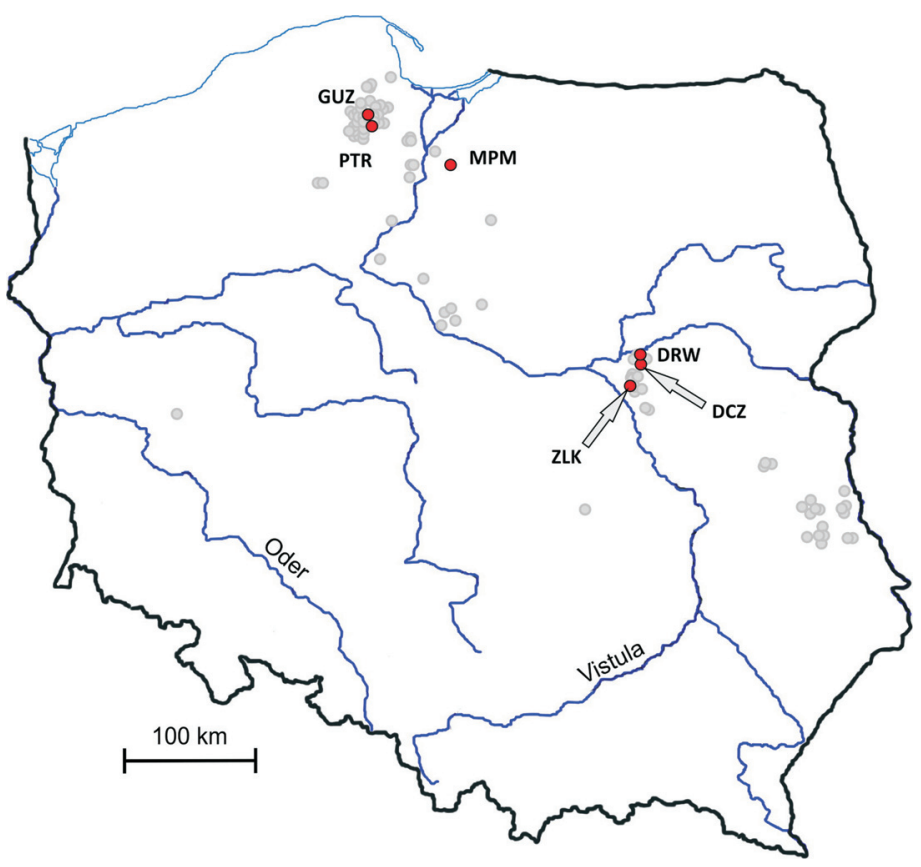

Figure 1. Present distribution of Eupallasella percnurus sites in Poland (grey circles) and sampling sites (red circles): DRW - Dręszew, DCZ - Działy Czarnowskie, ZLK - Zielonka, GUZ - Guzy, PTR - Piotrowo, MPM Mikołajki Pomorskie.

Table 1

General characteristics of sampling sites where male E. percnurus were caught

\begin{tabular}{lllll}
\hline \hline Habitat name* & $\begin{array}{l}\text { Geographical } \\
\text { location }\end{array}$ & $\begin{array}{l}\text { Water surface } \\
\text { (ha) }\end{array}$ & $\begin{array}{l}\text { Water pH } \\
\text { (units) }\end{array}$ & $\begin{array}{l}\text { Electrolytic conductivity } \\
\left(\mu S \mathrm{~cm}^{-1}\right)\end{array}$ \\
\hline \hline Dręszew (DRW) & $52^{\circ} 30^{\prime} 11^{\prime \prime} \mathrm{N} ; 21^{\circ} 19^{\prime} 03^{\prime \prime} \mathrm{E}$ & 0.22 & $5.70-7.62$ & $66-93$ \\
Działy Czarnowskie (DCZ) & $52^{\circ} 28^{\prime} 46^{\prime \prime} \mathrm{N} ; 21^{\circ} 14^{\prime} 52^{\prime \prime} \mathrm{E}$ & 1.00 & $6.37-6.57$ & $103-106$ \\
Zielonka (ZLK) & $52^{\circ} 17^{\prime} 51^{\prime \prime} \mathrm{N} ; 21^{\circ} 08^{\prime} 28^{\prime \prime} \mathrm{E}$ & 0.08 & $6.68-7.30$ & $228-399$ \\
Guzy (GUZ) & $54^{\circ} 08^{\prime} 44^{\prime \prime} \mathrm{N} ; 18^{\circ} 19^{\prime} 17^{\prime \prime} \mathrm{E}$ & 0.16 & $7.91-8.44$ & $56-136$ \\
Piotrowo (PTR) & $54^{\circ} 11^{\prime} 13^{\prime \prime} \mathrm{N} ; 18^{\circ} 09^{\prime} 14^{\prime \prime} \mathrm{E}$ & 0.07 & $5.37-6.25$ & $29-36$ \\
Mikołajki Pomorskie (MPM) & $53^{\circ} 50^{\prime} 19^{\prime \prime} \mathrm{N} ; 19^{\circ} 10^{\prime} 44^{\prime \prime} \mathrm{E}$ & 0.10 & $6.63-7.45$ & $50-93$ \\
\hline \hline
\end{tabular}

Abbreviated names of the populations are in parentheses.

Sperm motility characteristics, i.e. the percentage of motile sperm and straight line velocity (VSL), were determined using a two-step procedure described by Wojtczak et al. (2007) with modifications by Dietrich

\footnotetext{
Abbreviated names of the populations are in parentheses.
} 
et al. (2014). All motility measurements were made at least in duplicate for each sample of a minimum of 50 sperm per record. The spectrophotometric method was used for measurements of sperm concentration (Ciereszko and Dabrowski 1993).

Prior to data statistical analysis, percentages were normalized via arc-sin transformation. The values of fish size and sperm quality and quantity parameters presented in Table 2 were analyzed using one-way analysis of variance (ANOVA), followed by Tukey's test for post hoc comparisons of means. All analyses were performed at a significance level of $\mathrm{P}<0.05$ using GraphPad Prism 5.02 (GraphPad Software Inc; www.graphpad.com). Pearson's correlation was used to determine the strength and direction of the relationship between semen volume and fish body weight and total length. These analyses were performed using Statistica 8 for Windows (Statsoft, Inc.).

\section{Results}

Considerable differences in fish size and semen volume and quality were found among the males from the populations analyzed (Table 2). The largest males were from the DCZ and MPM populations (3.36-3.73 g, respectively). The smallest, with a body mass of $1.38 \mathrm{~g}$, were from the DRW population. The highest condition factor of 0.97-0.99 was noted in the fish from the PTR and MPM populations, whereas the lowest value was noted in fish from the ZLK population $(\mathrm{K}=0.82)$.

The milt volume and sperm concentration of the lake minnow males from the populations investigated were markedly different. Milt from the smallest males from the DRW population had the lowest total volume of $36 \mu \mathrm{l}$ (Table 2). The highest semen volume of $112 \mu \mathrm{l}$ was noted in males from the MPM population, which was one of the largest. Likewise, when calculated per gram of fish body weight, the highest semen volume was recorded in the MPM population. Average sperm concentrations differed among populations from about $5 \times 10^{9} \mathrm{ml}^{-1}$ to $8 \times 10^{9} \mathrm{ml}^{-1}$ in fish from the MPM population.

A positive linear correlation was found between total semen volume and fish body weight $(\mathrm{r}=0.61$; $\mathrm{y}$ $=17.45 \mathrm{BW}+12.64 ; \mathrm{P}=0.0000)$. A similar correlation was noted between semen volume and fish total length $(\mathrm{r}=0.55 ; \mathrm{y}=1,79-58.37 \mathrm{TL} ; \mathrm{P}=0.0000)$.

Mean values of sperm motility were similar and ranged from 86.2 in fish from the PTR population to $88.6 \%$ in fish from the MPM population (Table 2); however, there were population related differences in sperm velocity measured by VSL. The highest mean

Table 2

Fish biometric parameters and semen characteristics of lake minnow, E. percnurus, males caught at different sampling sites in Poland

\begin{tabular}{lllllll}
\hline \hline Parameter & DRW $(\mathrm{n}=50)$ & DCZ $(\mathrm{n}=50)$ & ZLK $(\mathrm{n}=50)$ & GUZ $(\mathrm{n}=50)$ & PTR $(\mathrm{n}=50)$ & MPM $(\mathrm{n}=50)$ \\
\hline \hline Body mass $(\mathrm{g})$ & $1.38 \pm 0.57^{\mathrm{d}}$ & $3.73 \pm 0.92^{\mathrm{a}}$ & $1.97 \pm 0.74^{\mathrm{b}}$ & $1.71 \pm 0.47^{\mathrm{c}}$ & $1.97 \pm 0.33^{\mathrm{b}}$ & $3.36 \pm 0.84^{\mathrm{a}}$ \\
Total length $(\mathrm{mm})$ & $52.8 \pm 6.6^{\mathrm{d}}$ & $74.9 \pm 5.7^{\mathrm{a}}$ & $61.1 \pm 7.2^{\mathrm{b}}$ & $57.0 \pm 4.8^{\mathrm{c}}$ & $58.6 \pm 2.8^{\mathrm{c}}$ & $69.1 \pm 5.2^{\mathrm{a}}$ \\
Condition factor K & $0.91 \pm 0.05^{\mathrm{abc}}$ & $0.87 \pm 0.06^{\mathrm{bc}}$ & $0.82 \pm 0.07^{\mathrm{c}}$ & $0.90 \pm 0.07^{\mathrm{abc}}$ & $0.97 \pm 0.06^{\mathrm{ab}}$ & $0.99 \pm 0.04^{\mathrm{a}}$ \\
Total semen volume $(\mu \mathrm{l})$ & $36.0 \pm 19.4^{\mathrm{d}}$ & $59.0 \pm 44.9^{\mathrm{b}}$ & $39.7 \pm 17.9^{\mathrm{d}}$ & $50.5 \pm 18.5^{\mathrm{c}}$ & $49.3 \pm 12.9^{\mathrm{c}}$ & $112.0 \pm 16.9^{\mathrm{a}}$ \\
Semen volume & $26.2 \pm 6.4^{\mathrm{bc}}$ & $15.2 \pm 7.9^{\mathrm{e}}$ & $20.5 \pm 6.8^{\mathrm{d}}$ & $30.0 \pm 8.9^{\mathrm{ab}}$ & $25.4 \pm 6.5^{\mathrm{c}}$ & $34.3 \pm 4.8^{\mathrm{a}}$ \\
$\left(\mu \mathrm{g} \mathrm{g}^{-1} \mathrm{BW}\right)$ & & & & & \\
Sperm concentration & $6.2 \pm 2.7^{\mathrm{b}}$ & $4.7 \pm 2.3^{\mathrm{c}}$ & $5.9 \pm 2.4^{\mathrm{b}}$ & $4.8 \pm 1.5^{\mathrm{c}}$ & $5.2 \pm 1.8^{\mathrm{c}}$ & $8.0 \pm 1.5^{\mathrm{a}}$ \\
$\left(\times 10^{9} \mathrm{ml}^{-1}\right)$ & & & & & \\
Motile sperm $(\%)$ & $88.3 \pm 10.5^{\mathrm{a}}$ & $86.7 \pm 9.9^{\mathrm{a}}$ & $87.0 \pm 12.5^{\mathrm{a}}$ & $87.4 \pm 10.0^{\mathrm{a}}$ & $86.2 \pm 14.0^{\mathrm{a}}$ & $88.6 \pm 10.9^{\mathrm{a}}$ \\
VSL $\left(\mu \mathrm{m} \mathrm{s}^{-1}\right)$ & $103.2 \pm 32.6^{\mathrm{c}}$ & $100.7 \pm 30.7^{\mathrm{c}}$ & $112.7 \pm 32.7^{\mathrm{b}}$ & $127.0 \pm 39.6^{\mathrm{a}}$ & $96.3 \pm 33.4^{\mathrm{c}}$ & $106.3 \pm 32.7^{\mathrm{bc}}$ \\
\hline \hline
\end{tabular}

Abbreviations of the population names as in Table 1. Results obtained for different populations are presented as means \pm SD. Data in rows marked with different superscripts differ significantly at $\mathrm{P}<0.05$. 
value of VSL was determined in sperm from the GUZ population $\left(127 \mu \mathrm{m} \mathrm{s}^{-1}\right)$, whereas the lowest values were determined for the DRW, MPM, and PTR populations (96.3-106.3 $\mu \mathrm{m} \mathrm{s}^{-1}$ ).

\section{Discussion}

Polish lake minnow populations inhabit small, shallow water bodies with environmental conditions ranging from dystrophy to eutrophy. Physical and chemical water properties in the habitats such as water temperature, $\mathrm{pH}$, oxygen saturation, conductivity, and other parameters differ considerably (Wolnicki et al. 2008, Kamiński et al. 2011). These differences were reflected in fish size and the amount of sperm and its quality.

In this study high positive correlations between lake minnow male size (body weight and total length) and total semen volume were noted. The largest total volume of semen was obtained from the largest males in the MPM population, while the smallest total volume was obtained from the smallest males in the DRW population.

Despite the large differences in habitat conditions, the motility of lake minnow sperm did not differ among the populations, but substantial differences were found in sperm concentration and VSL. Although these parameters varied significantly, it was difficult to determine relations among them or to different environmental conditions. These differences, however, suggested different reproductive potential in lake minnow males among populations. It is known that sperm quality in fish can be affected by biotic and abiotic factors and is dependent on complex interactions among genetic, physiological, and environmental factors (Rurangwa et al. 2004). However, in our study it could not be determined to what extent the differences among lake minnow populations originated from genetic or physiological differences or environmental conditions. Differences in fish sperm quality are known to occur, even under similar hatchery conditions (Judycka et al. 2019).
In the present study, the males were stimulated with Ovopel ${ }^{\odot}$, and they had increased semen volume (up to $112 \mu \mathrm{l}$ ) and lower sperm concentration (4.7-8.0 $\times 10^{9} \mathrm{ml}^{-1}$ ) in comparison to non-stimulated $E$. percnurus males from other studies (Dietrich et al. 2011, 2014). The typical semen volume of non-stimulated males was 18.6-36.3 $\mu \mathrm{l}$ and the sperm concentration was 8.9-14.7 $\times 10^{9}$ $\mathrm{ml}^{-1}$ (Dietrich et al. 2014). Semen volume in non-stimulated males can also be even lower and the sperm concentration much higher. For example, in the ZLK population that was investigated several years earlier by Dietrich et al. (2011), fish semen volume was minute $(<9 \mu \mathrm{l})$ with a very high sperm concentration $\left(20.8 \times 10^{9} \mathrm{ml}^{1}\right)$. However, in other cyprinids, for example in non-stimulated common carp, Cyprinus carpio (L.), the reported sperm concentration was even as high as $30.8 \times 10^{9} \mathrm{ml}^{-1}$ (Dietrich et al. 2019).

It is well known that hormonal stimulation usually does not affect semen quality parameters such as the percentage of sperm motility, motility duration, or sperm velocity (Mylonas et al. 2017). These facts enabled us to compare these parameters among the six populations. Computer - assisted sperm analysis (CASA) showed that sperm in hormonally stimulated lake minnow males had a motility rate very similar to non-stimulated fish and comparable values of straight line velocity.

In conclusion, the quality of semen obtained from E. percnurus males from six different Polish populations, though diversified, was considered to be high in all cases. Therefore, it was determined to be useful for both artificial reproduction and cryopreservation.

Acknowledgments. We would like to thank Grzegorz J. Dietrich for his valuable assistance in laboratory work. The present study was conducted as part of project No. 2014/15/B/NZ9/05240 granted by the National Science Centre (Poland) for 2015-19.

Author contributions. J.W. designed the study; J.W., J.S, and R.K. collected the fish; S.J. performed the study with the assistance of J.S., J.W., and R.K.; S.J. and R.K. analyzed the data; J.S. and S.J. wrote the paper. 
ORCID ID

Justyna Sikorska (iD) http://orcid.org/0000-0001-8575-7034

Sylwia Judycka (iD) https://orcid.org/0000-0002-1410-3866

Rafał Kamiński iD https://orcid.org/0000-0002-8138-3327

Jacek Wolnicki iD https://orcid.org/0000-0003-4396-390X

\section{References}

Ciereszko A., Dabrowski K. 1993 - Estimation of sperm concentration of rainbow trout, whitefish and yellow perch using a spectrophotometric technique - Aquaculture 109: 367-373.

Dietrich G., Pecio A., Sikorska J., Wolnicki J., Słowińska J., Hliwa P., Kamiński R., Andronowska A., Ciereszko A. 2014 - Characterization of lake minnow Eupallasella percnurus semen in relation to sperm morphology, regulation of sperm motility and interpopulation diversity - J. Fish Biol. 85: 446-455.

Dietrich G.J., Wolnicki J., Słowińska M., Sikorska J., Hliwa P., Kamiński R., Ciereszko A. 2011 - Preliminary characteristics of lake minnow, Eupallasella percnurus (Pall.), semen - Arch. Pol. Fish. 19: 133-136.

Dietrich G., Wolnicki J., Słowińska M., Sikorska J., Hliwa P., Kamiński R., Liszewska E., Ciereszko A. 2015 Short-term storage and cryopreservation of lake minnow Eupallasella percnurus (Pallas, 1814) sperm - J. Appl. Ichthyol. 31: 75-78.

Dietrich M.A., Irnazarow I., Inglot M., Adamek M., Jurecka P., Steinhagen D., Ciereszko A. 2019 - Hormonal stimulation of carp is accompanied by changes in seminal plasma proteins associated with the immune and stress responses - J. Proteomics 200: 103369, https://doi.org/10.1016/j.jprot.2019.04.019.

Horváth L., Szabó T., Burke J. 1997 - Hatchery testing of GnRH analogue-containing pellets on ovulation in four cyprinid species - Pol. Arch. Hydrobiol. 44: 221-226.

Judycka S., Nynca J., Liszewska E., Mostek A., Ciereszko A. 2019 - Comparative analysis of sperm freezability of sex-reversed female brook trout and sex-reversed female rainbow trout semen - Aquaculture 498: 201-207.

Kaczmarczyk D., Wolnicki J. 2016 - Genetic diversity of the critically endangered lake minnow Eupallasella percnurus in Poland and its implications for conservation - PLoS ONE 11(12): e0168191, .

Kamiński R., Kusznierz J., Myszkowski L., Wolnicki J. 2004 The first attempt to artificially reproduce the endangered cyprinid lake minnow Eupallasella perenurus (Pallas) Aquacult. Int. 12: 3-10.

Kamiński R., Wolnicki J., Sikorska J. 2011 - Physical and chemical water properties in water bodies inhabited by the endangered lake minnow, Eupallasella percnurus (Pall.), in central Poland - Arch. Pol. Fish. 19: 153-159.

Mylonas C.C., Duncan N.J., Asturiano J.F. 2017 - Hormonal manipulations for the enhancement of sperm production in cultured fish and evaluation of sperm quality Aquaculture 472: 21-44.

Rurangwa E., Kime D.E., Ollevier F., Nash J.P. 2004 - The measurement of sperm motility and factors affecting sperm quality in cultured fish - Aquaculture 234: 1-28.

Sowińska-Świerkosz B., Kolejko M. 2019 - Extinction risk to lake minnow (Eupallasella percnurus) due to habitat loss: Eastern Poland case study - Environ. Monit. Assess. 191 (9): 571, https://doi.org/10.1007/s10661-019-7731-6.

Wojtczak M., Dietrich G. J., Irnazarow I., Jurecka P., Słowińska M., Ciereszko A. 2007 - Polymorphism of transferrin of carp seminal plasma: relationship to blood transferrin and sperm motility characteristics - Comp. Physiol. Biochem. 148: 426-431.

Wolnicki J., Kamiński R., Sikorska J. 2011 - Occurrence, threats and active protection of the lake minnow, Eupallasella percnurus (Pall.) in Mazowieckie Voivodeship in Poland - Arch. Pol. Fish. 19: 209-216.

Wolnicki J., Kaminski R., Sikorska J., Kaczmarczyk D. 2019 - Occurrence and active protection of the endangered cyprinid fish species, lake minnow Eupallasella percnurus (Pall.), in Poland - In: XVI European Congress of Ichthyology Lausanne, Swiss, 2-6 September 2019. Frontier of Marine Science, Conference Abstract: XVI European Congress of Ichthyology, 206-208.

Wolnicki J., Kolasa Sz., Sikorska J. 2018 - Restoration of lake minnow Eupallasella percnurus in the Polesie National Park - Chrońmy Przyr. Ojcz. 74: 117-125 (in Polish).

Wolnicki J., Sikorska J., Kamiński R. 2008 - Occurrence and conservation of the endangered cyprinid fish species lake minnow Eupallasella percnurus (Pallas, 1814) in the Mazowieckie Voivodeship in Poland - Teka Kom. Ochr. Kszt. Srod. Przyr. 5: 190-198. 